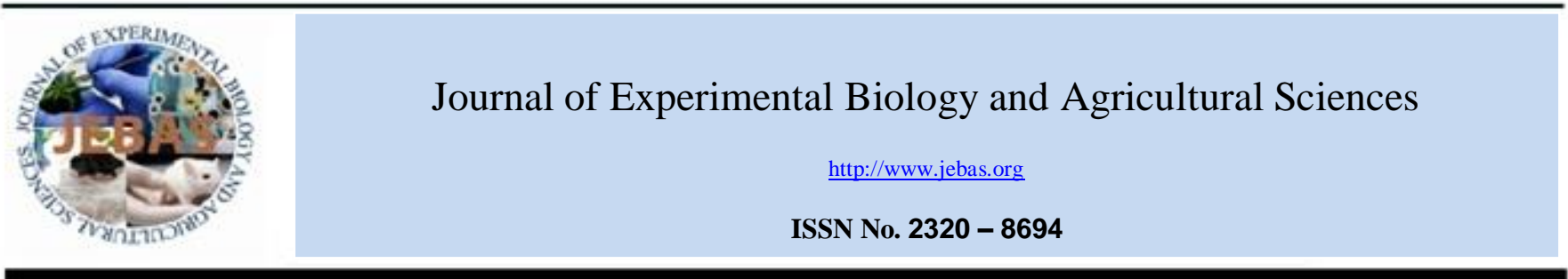

\title{
MORPHOLOGICAL DESCRIPTION OF NOVEL PHAIUS PRIMARY HYBRID (ORCHIDACEAE)
}

\author{
R. Devadas*, R. K. Pamarthi, A. L. Meitei, S. L. Pattanayak, R. Sherpa \\ Plant Breeding, ICAR-National Research Centre on Orchids Pakyong-737106, Sikkim, India
}

Received - December 13, 2018; Revision - February 14, 2019; Accepted - March 22, 2019

Available Online - April 10, 2019

DOI: http://dx.doi.org/10.18006/2019.7(2).138.147

\section{KEYWORDS \\ Phaius tankervilleae \\ P. flavus \\ Orchidaceae \\ Primary species hybrid \\ Characterization}

\begin{abstract}
Popularly known nun orchid or swamp orchid (Phaius sps.) is listed as endangered species under Schedule-I of Indian Wild Life (Protection) Act, 1972. Natural Phaius hybrids were not reported and present study is an attempt to develop a new Phaius species by using two native species viz., Phaius tankervilleae (Banks ex l'Heritier) Bl and Phaius flavus (Blume) Lindl. Result of present study suggests crossability and compatibility between these two species which helped in synthesize novel hybrid species. New Phaius hybrid produced flowers with dominating yellow-orange colour (RHS 17B/A) sepals and petals are bright crimson colour (RHS 175B) with elongated stripes on lip inside. First flowering of Phaius cross progenies (PBX-11-22) was observed in Jan-Mar, 2017 with regular flowering habit in consecutive seasons. Comparison with parents indicated distinct nature in floral attributes. Unlike Phaius flavus, the sepals and petals of novel progenies have spreading nature. Flower size varies from 7-8 x 8.5-9 cm with mild fragrance on shiny and warm days. Sequential flowering in acropetal fashion with 8-10 florets observed on moderately strong spike with potted vase life $>40$ days.
\end{abstract}

* Corresponding author

E-mail: ramgopal.devadas@icar.gov.in (R. Devadas)

Peer review under responsibility of Journal of Experimental Biology and Agricultural Sciences.

Production and Hosting by Horizon Publisher India [HPI] (http://www.horizonpublisherindia.in/).

All rights reserved.
All the article published by Journal of Experimental Biology and Agricultural Sciences is licensed under a Creative Commons Attribution-NonCommercial 4.0 International License Based on a work at www.jebas.org.

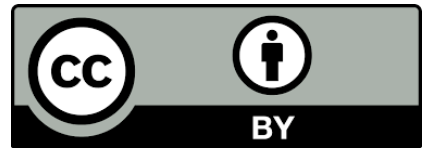




\section{Introduction}

Genus Phaius was established by Jao de Loureiro 1790 in Flora Cochinchinensis and comprises more than 30 species around tropical parts of Old world from Asia, Australia, Africa and various islands of Pacific and Indian oceans (Loureiro, 1790; Lucksom, 2007; Chowdhery \& Agrawala, 2013). Phaius tankervilleae was introduced in England in 1778 from China by John Fothergill. With course of time, these species were naturalized by introduction in South America, Caribban Islands; Central America (Panama) and was listed in catalogue of plant species at Royal Botanical Gardens, Kew (Desmond, 1995) and The European Garden Flora (Cullen et al., 2011). In India, few species are naturally available in North-Eastern states and legally categorized as endangered; and it was protected under Schedule-I of Indian Wild Life (Protection) Act, 1972 and has serious trade restrictions on international commercial export selling's under Appendix-II of international conventions (Bhuyan, 2010; CITES, 2016). Efforts were also initiated for conservation through long-term seed storage (Hirano et al., 2009) and mass multiplication (Malemnganba et al., 1994). Both in-situ and ex-situ conservation programmes of P. tankervilleae were initiated in India (Kanwal, 2014). Presence of $P$. tankervilleae from other Indian states like Uttarakhand from Corbett National Park, North-Western Himalaya (Naithani et al., 2009) and Southern India (George \& Mathew, 2016) indicates spatial distribution in India. P. flavus (Blume) Lindl., geographically located in Assam, Eastern Himalayas and $P$. mishmensis (Lindl. \& Paxton) Rchb., and P. nanus Hook.f., are the other common Phaius species available in India (Pearce \& Cribb, 2002).

Phaius orchids are considered as highly decorative and have great ornamental value with long inflorescences, bigger size flowers, more florets \& different colours with evergreen long broad elliptic pleated leaves suitable indoor cultivation; otherwise often treated as invasive orchids (Ackerman, 2012). Even it has medicinal application in traditional medicine and used in natural dye indigo preparations in Arunachal Pradesh (Kanwal, 2014). The predominant brownish-blue hue of flowers especially when old or damaged may indicate the presence of rich chemicals (Pearce \& Cribb, 2002).

Generally, $P$. tankervilleae is very commonly cultivated than other species (Schuiteman \& de Vogel, 2000). However, the commercial varieties of Phaius are unavailable for domestic cultivation and not registered under 'Protection of Plant Varieties and Farmers Rights Act, 2002' for Plant Breeder's rights in India. At international level, various experiments were conducted at large scale to develop novel Grex/hybrids (https://www.orchids.org/grexes/phaius-magniflorus); but only few hybrids are available within closed circuits by amateur growers, which are not yet legally protected nor notified by Plant Variety Protection (PVP) of TRIPS agreement or similar governing laws enacted under Patent Cooperation Treaty (http://www.aos.org/orchids/orchids-a-to-z/letter-p/phaius.aspx).

Further, the occurrence of natural hybrids involving wild species was not reported so far in genus Phaius. Nototribic mode of pollination assisted by insects was found in Phaius tankervilleae (Banks ex L'Herit) Bl (Buragohain et al., 2016). However, auto self pollination was absent due to obstructive floral structures, although genetic barriers were never reported (Bhuyan, 2010). Royal Horticultural Society (RHS) data base reveals only one hybrid 'Ashworthianus' obtained from P. flavus (seed parent) and $P$. wallichii (male parent) in 1893 by Sanders (St Albans). So far, no hybrid registered with $P$. flavus and P. tankervilleae as parents for both direct and reciprocal crosses (http://apps.rhs.org.uk/horticulturaldatabase/orchidregister/orchi dregister.asp). Development of hybrids using rare and endangered species for commercial sales will reduce the threatening pressure on their wild species (Kishor \& Sharma, 2009). At gobal level, there are no trade restrictions on hybrids derived from Orchid species for import and exports as per 'Convention on International Trade in Endangered of Wild Flora and Fauna' (CITES, 2004; Devadas et al., 2010). Hence, in present study an attempt has been made to develop new interspecific hybrid using native indigenous species available and novel progeny generated characterized at flowering stage to assess the taxonomic and breeding value for further genetic improvement.

\section{Materials and methods}

\subsection{Mother plants}

Phaius species viz., P. tankervilleae (Banks ex l'Heritier) Bl., and P. flavus (B1.) Lindl. were used as parent material in the present studies, these were catalogued species accessions from the 'National Active Germplasm Site' (NAGS) collections at ICAR-NRC on Orchids, Pakyong, Sikkim.

\subsection{Hybridization programme}

A series of crossing programme was carried out with Phaius species and other orchid species from 2005 to 2014 to assess the cross compatibility nature, with long term objective to generate novel inter-specific and inter-generic hybrids for Orchid genetic improvement. Based on flowering synchrony, Phaius species were crossed with other species and hybrids from other genera for several years viz., Paplionanthe, Calanthe, Dendrobium, Dienia, Coelogyne, Phalaenopsis, Lycaste, Thunia, Cymbidium, Arundina, Paphiopedilum, Vanda, Coelogyne and Vanda group (Table 1). 
Table 1 List of crosses attempted in Phaius with other Orchids and pod set status

\begin{tabular}{|c|c|c|c|c|}
\hline S. no & Cross code & Female parent & Male parent & Pod set \\
\hline 1 & PBS-05-271, 272 & P. tankervilleae & (selfing) & $\sqrt{ }$ \\
\hline 2 & PBS-05-273, 274 & Paplionanthe teres & P. tankervilleae & $\mathrm{x}$ \\
\hline 3 & PBX-05-279, 280 & P. tankervilleae & Calanthe masuca & $\mathrm{x}$ \\
\hline 4 & PBX-05-289 & P. tankervilleae & D. moschatum & $\mathrm{x}$ \\
\hline 5 & PBX-05-290 & Calanthe masuca & P. tankervilleae & $\sqrt{ } / \mathrm{x}$ \\
\hline 6 & PBX-05-328 & P. tankervilleae & Dienia ophrydis & $\mathrm{x}$ \\
\hline 7 & PBX-05-1009 to 1011 & D. aphyllum & P. flavus & $\mathrm{x}$ \\
\hline 8 & PBX-05-1012 to 1014 & P.flavus & D. aphyllum & $\mathrm{x}$ \\
\hline 9 & PBX-05-1015 to 1016 & D. nobile & P. flavus & $\mathrm{x}$ \\
\hline 10 & PBX-05-1017 to 1018 & P. flavus & D. nobile & $\mathrm{x}$ \\
\hline 11 & PBX-05-1019 & P. flavus & (selfing) & $\mathrm{x}$ \\
\hline 12 & PBX-05-1024 to 1025 & Coelogyne flaccida & P. flavus & $\mathrm{x}$ \\
\hline 13 & PBX-06-20 to 21 & P. flavus & Phalaenopsis lobbii & $\mathrm{x}$ \\
\hline 14 & PBX-06-22 to 23 & Phalaenopsis lobbii & P. flavus & $\mathrm{x}$ \\
\hline 15 & PBX-06-24 & P. flavus & D. nobile & $\mathrm{x}$ \\
\hline 16 & PBX-06-25 & D. nobile & P. flavus & $\mathrm{x}$ \\
\hline 17 & PBX-06-59 & P.flavus & Lycaste crueata & $\mathrm{x}$ \\
\hline 18 & PBX-06-60 & Lycaste crueata & P. flavus & $\mathrm{x}$ \\
\hline 19 & PBX-06-78 & Lycaste crueata & P. tankervilleae & $\sqrt{ } / \mathrm{x}$ \\
\hline 20 & PBX-06-79 & P. tankervilleae & Lycaste crueata & $\mathrm{x}$ \\
\hline 21 & PBX-06-84 & P. flavus & Lycaste crueata & $\mathrm{x}$ \\
\hline 22 & PBX-06-85 & Lycaste crueata & P. flavus & $\mathrm{x}$ \\
\hline 23 & PBS-06-129 to 132 & P. tankervilleae & (selfing) & $\sqrt{ }$ \\
\hline 24 & PBX-06-143 & C. 'Sheragreen' & P. tankervilleae & $\mathrm{x}$ \\
\hline 25 & PBX-06-144 & P. tankervilleae & C. 'Sheragreen' & $\mathrm{x}$ \\
\hline 26 & PBX-06-307 & Calanthe triplicata & P. tankervilleae & $\mathrm{x}$ \\
\hline 27 & PBX-06-308 & P. tankervilleae & Calanthe triplicata & $\sqrt{ } / \mathrm{x}$ \\
\hline 28 & PBX-06-339 & P. tankervilleae & Thunia marshalliana & $\mathrm{x}$ \\
\hline 29 & PBX-06-340 & Thunia marshalliana & P. tankervilleae & $\mathrm{x}$ \\
\hline 30 & PBX-06-376 & C. aloifolium & P. tankervilleae & $\mathrm{x}$ \\
\hline 31 & PBX-06-377 & P. tankervilleae & C. aloifolium & $\mathrm{x}$ \\
\hline 32 & PBX-06-411 to 412 & P. tankervilleae & (selfing) & $\sqrt{ }$ \\
\hline 33 & PBX-06-465 to 466 & P. tankervilleae & Arundina graminifolia & $\mathrm{x}$ \\
\hline 34 & PBS-06-473 & P. tankervilleae & (selfing) & $\sqrt{ }$ \\
\hline 35 & PBX-07-21 & Lycaste crueata & P. tankervilleae & $\mathrm{X}$ \\
\hline 36 & PBX-07-22 & P. tankervilleae & Lycaste crueata & $\mathrm{x}$ \\
\hline 37 & PBX-09-01 & P. tankervilleae & Lycaste crueata & $\mathrm{X}$ \\
\hline 38 & PBX-09-02 & Lycaste crueata & P. tankervilleae & $\mathrm{x}$ \\
\hline
\end{tabular}

Journal of Experimental Biology and Agricultural Sciences http://www.jebas.org 
Table 1 List of crosses attempted in Phaius with other Orchids and pod set status

\begin{tabular}{|c|c|c|c|c|}
\hline S. no & Cross code & Female parent & Male parent & Pod set \\
\hline 39 & PBX-09-03 & P. tankervilleae & P. teres & $\sqrt{ } / x$ \\
\hline 40 & PBX-09-04 & P.teres & P. tankervilleae & $\mathrm{x}$ \\
\hline 41 & PBX-11-21, 22, 23 & P. tankervilleae & P. flavus & $\sqrt{ }$ \\
\hline 42 & PBX-11-24, 25, 26 & P. flavus & P. tankervilleae & $\sqrt{ }$ \\
\hline 43 & PBX-13-144 & Lycaste crueata & P. tankervilleae & $\mathrm{x}$ \\
\hline 44 & PBX-13-145 & P. tankervilleae & Lycaste crueata & $\mathrm{x}$ \\
\hline 45 & $\begin{array}{l}\text { PBSx-13-146, } \\
\text { PBSx-14-208 }\end{array}$ & P. tankervilleae & (natural selfing) & $\sqrt{ }$ \\
\hline 46 & PBX-14-255 & C. 'Soul Hunt-I' & P. tankervilleae & $\mathrm{x}$ \\
\hline 47 & PBX-14-256 & P. tankervilleae & C. 'Soul Hunt-I' & $\mathrm{x}$ \\
\hline 48 & PBX-14-257 & C. 'PCMV' & P. tankervilleae & $\mathrm{x}$ \\
\hline 49 & PBX-14-258 & P. tankervilleae & C. 'PCMV' & $\mathrm{x}$ \\
\hline 50 & PBX-14-259 & C. Unknown hybrid & P. tankervilleae & $\mathrm{x}$ \\
\hline 51 & PBX-14-260 & P. tankervilleae & C. Unknown hybrid & $\mathrm{x}$ \\
\hline 52 & PBX-14-261 & C. 'Fire Storm Blaze' & P. tankervilleae & $\mathrm{x}$ \\
\hline 53 & PBX-14-262 & P. tankervilleae & C. 'Fire Storm Blaze' & $\mathrm{x}$ \\
\hline 54 & PBX-14-263 & C. 'Caripepper Peach Keen' & P. tankervilleae & $\mathrm{x}$ \\
\hline 55 & PBX-14-264 & P. tankervilleae & C. 'Caripepper Peach Keen' & $\mathrm{x}$ \\
\hline 56 & PBX-14-265 & P. villosum (\#2410) & P. tankervilleae & $\sqrt{ } / \mathrm{x}$ \\
\hline 57 & PBX-14-266 & P. tankervilleae & P. villosum (\#2410) & $\mathrm{x}$ \\
\hline 58 & PBX-14-267 & $V$. 'Berniece Miller' & P. tankervilleae & $\mathrm{x}$ \\
\hline 59 & PBX-14-268 & P. tankervilleae & $V$. 'Berniece Miller' & $\mathrm{x}$ \\
\hline 60 & PBX-14-269 & D. 'Emma White' & P. tankervilleae & $\mathrm{x}$ \\
\hline 61 & PBX-14-270 & P. tankervilleae & D. 'Emma White' & - \\
\hline 62 & PBX-14-271 & $V$. 'Berniece Miller' & P. tankervilleae & $\mathrm{x}$ \\
\hline 63 & PBX-14-272 & P. tankervilleae & $V$. 'Berniece Miller' & $\mathrm{x}$ \\
\hline 64 & PBX-14-273 & C. flaccida var cristata & P. tankervilleae & $\mathrm{x}$ \\
\hline 65 & PBX-14-274 & P. tankervilleae & C. flaccida var cristata & $\sqrt{ } / x$ \\
\hline 66 & PBX-14-275 & P. vandarum & P. tankervilleae & $\mathrm{x}$ \\
\hline 67 & PBX-14-276 & P. tankervilleae & P. vandarum & $\mathrm{x}$ \\
\hline 68 & PBX-14-277 & E.pubescens & P. tankervilleae & $\mathrm{x}$ \\
\hline 69 & PBX-14-278 & P. tankervilleae & E.pubescens & $\mathrm{x}$ \\
\hline \multicolumn{3}{|c|}{ Total number of self pollinations (12 no.) } & & $91.67 \%$ \\
\hline \multicolumn{3}{|c|}{ Total number of cross pollinations (79 no.) } & & $13.18 \%$ \\
\hline \multicolumn{3}{|c|}{ Total number of crosses germinated (13 no.) } & & $14.28 \%$ \\
\hline \multicolumn{3}{|c|}{ Total number of crosses germinated excluding selfing (6 no.) } & & $6.59 \%$ \\
\hline \multicolumn{3}{|c|}{ Total number of pedigree germinated excluding selfing (2 no.) } & & $2.19 \%$ \\
\hline
\end{tabular}

$(\sqrt{ }$ - success of pod set, $x$ - failure of pod set, $\sqrt{ } / x$ - success of pod set/no germination 
The hybridization was done by emasculation of female flowers by removing anther cap and pollinia. Fresh pollinia were collected from male parent and attached to stigma surface of the column for pollination. Both direct and reciprocal crosses were made using $P$. tankervilleae (Banks ex l'Heritier) Bl., and $P$. flavus (B1.) Lindl. at ICAR-NRC Orchids, Sikkim. One to two flowers were crossed for each combination due to limitation of flowering plants availability. Generally the stigmatic surface of female plants was highly receptive and sticky; however the pollen bags were used to cover the inflorescence to avoid cross pollination with insects. Once the pollination succeeded, flower colour changed in to dark and lip dries after 3-4 days and success of pod set was presented in Table 1. Few crosses were made by selfing using pollen of the same flower on stigma to understand self compatibility among Phaius species.

\subsection{Progeny development}

Mature ellipsoid capsules were harvested after 10-11 months from pod formation after crossing and seedlings were raised using in-vitro techniques. The response of in-vitro studies will be discussed in separate paper. Among the capsules obtained from crosses, seedlings were obtained from selfed progenies and crossed progenies from PBX-11-21 (direct cross) and PBX-1125 (reciprocal cross) series. Progenies of PBX-11-21 and PBX11-25 flowered in early 2017 and mid 2018 after four and five years respectively after shifting seedlings for growing conditions under normal greenhouses. All the standard package practices for cultivation of Phaius progenies for growth were followed using pots (Devadas et al., 2008). Morphological characters are recorded at the full bloom stages and colour of the flowers was recorded with the help of 'Royal Horticultural Society' (RHS) colour chart (Simpson, 2011). The general descriptions for the morphological characters were based on quantitative data and expressivity of qualitative characters like flower colour at Pakyong, Sikkim (Altitude 1,300 MSL) location are recorded.

\section{Results \& Discussion}

\subsection{Success of hybridization}

A total of 91 handmade pollinations were made that includes self pollinations to study both cross compatibility and self incompatibility nature in Phaius species. All 12 crosses attempted for selfing in both species resulted $91.67 \%$ pod setting. The status of pod setting with other species and genera are presented in Table 1. Success of crossing at species and genera level was recorded $13.18 \%$ pod formation, with success rate of in-vitro seed germination at $14.28 \%$. Crosses viz., PBX05-290, PBX-06-78, PBX-06-308, PBX-09-03, PBX-14-265, PBX-14-274 resulted pod set, when P. tankervilleae was used as one of the parent in hybridization programme; however failed to achieve germination of seedlings. Number of pedigree crosses resulted viable seedlings, excluding selfed crosses is limited to $2.19 \%$ among crosses performed. Results indicate narrow genetic behaviour of Phaius with limited scope for response to genetic improvement through conventional hybridization programmes.

\subsection{Incompatibility behaviour of Phaius}

Sympodial orchids like Calanthe masuca, Lycaste crueata, Paphiopedilum villosum showed only capsule development, when used as female parents in the present study. Similarly, capsule development was recorded in $P$. tankervilleae, when Calanthe triplicata, Paplionanthe teres and Coelogyne flaccida var. cristata were used as male parents. It indicates the possibility of pollen influence due to presence of hormones on flower colour change as an indication of pollination with capsule formation, without producing viable seeds (Burg \& Dijkman, 1967; Arditti et al., 1971). High level of incompatibility was observed Phaius with other Orchid genera, like sympodial orchid viz., Calanthe, Coelogyne, Phalaenopsis, Lycaste, Dienia, Cymbidium, Thunia, Paphiopedilum, Coelogyne, Eria and monopodial orchids viz., Paplionanthe, Dendrobium, Arundina and Vanda (Table 1). Both the pre and post-zygotic barriers could be the reasons with Phaius for reproductive isolation between species and the genera for unsuccessful hybridizations (Edmands, 2002). The long journey of pollen grains that usually stimulate ovule formation after pollination, which is distinct in orchid reproductive system (Arditti, 1992) and hurdles in pollen tube elongation after pollen germination might operate among other incompatible crosses.

\subsection{Self and cross compatibility in Phaius}

In the present study the crosses viz., PBX-11-21 to 23 using $P$. tankervilleae as female parent and P. flavus as male parent (direct crosses) along with their reciprocal crosses (PBX-11-24 to 26) yielded capsule/ pod formation with viable progeny development. Similarly, except $P$. flavus the attempted self pollinations in $P$. tankervilleae formed capsule development along with successful progeny development. It is indicates the cross compatibility nature of species among Phaius and self compatible nature within species. The true hybridity of crosses was confirmed with F1 progeny testing and selfed progenies resulted female type of plants only.

\subsection{Description of novel of Phaius cross (PBX-11-22)}

The data was collected on mature flowering plants (F1) of Phaius cross (PBX-11-22) based on 'Common Descriptors of Orchids' essentially required by Plant breeders (Table 2). The comparative descriptions of hybrid with parental species for demarcation of floral traits are shown in Table 3. The new hybrid 
Table 2 Description of Phaius F1 progeny of PBX-11-22

\begin{tabular}{|c|c|}
\hline Character & Description of trait \\
\hline Plant & podial nature, $76--80 \mathrm{~cm}$ height, spreading between $53-70 \mathrm{~cm}$. \\
\hline Pseudobulbs & $9 \times 3.5 \mathrm{~cm}, 3$ to 5 number, conical to avoid shape, sheathed by leaf bases, $3-4$ annual cicatrices in old bulbs. \\
\hline Leaves & $\begin{array}{l}5-6 \text {, longest } 80 \times 8 \mathrm{~cm} \text {, medium green colour (RHS 143C), spreading above pseudostem, narrow elliptic-lanceolate, acute, } \\
\text { plicate, petiole long, pseudostem with sheath base } 20 \mathrm{~cm} \text { long. }\end{array}$ \\
\hline Inflorescence & $\begin{array}{l}1-2 \text {, emerge from base, erect, }>65 \mathrm{~cm} \text { long, with } 8 \text { pedicellate flowers; peduncle stout, long, }>14 \mathrm{~cm} \text { internodal length, } \\
\text { yellow-green colour (RHS 144B), smooth, } 4 \mathrm{~cm} \text { long, tubular, deep veined, sheathing bracts in medium yellow-green colour, } \\
\text { caducous; }\end{array}$ \\
\hline Flowers & $\begin{array}{l}8-10,7.5-9 \mathrm{~cm} \text {, acropetal flower opening, colour dominated by Yellow-orange (RHS 17B/A) sepals \& petals with faint } \\
\text { brownish shade, crimson colour on lip, moderately scented during shiny ward days with potted vase life of }>40 \text { days. }\end{array}$ \\
\hline Sepals & $\begin{array}{l}\text { sub-equal, fleshy spreading; dorsal sepal } 5 \times 1.8 \mathrm{~cm} \text {, narrow oblong, acute tip, } 7 \text { veins deep visible in same colour, yellow } \\
\text { colour (RHS 13B) on ventral side; lateral sepals elliptic oblong, inside margin slightly curved forward, median vein touchy } \\
\text { on ventral side. }\end{array}$ \\
\hline Petals & $\begin{array}{l}\text { size } 5.2 \times 2 \mathrm{~cm} \text {, oblanceolate, acute, seven nerved, sub equal, colour same as sepals, shiny yellow on ventral side, margin } \\
\text { slightly reflexed. }\end{array}$ \\
\hline Lip & $\begin{array}{l}5.5 \times 2 \mathrm{~cm} \text {, oblong, semi-concave, spreading, open type, mentum in yellow colour apprx. } 1.2 \mathrm{~cm} \text {, side lobes erect, yellow- } \\
\text { orange colour (RHS 17B/A); anterior lobe deflexed in middle, conchiform, corrugated; } 3 \text { obscure lamellae/calli become } \\
\text { prominent at disc, attractive with multiple crimson colour (RHS 175B) thick lines inside from base to tip of apical lobe, } \\
\text { crimson rich coloured at margin. }\end{array}$ \\
\hline Column & $2.5 \times 0.52 \mathrm{~cm}$, erect, incurved, white. \\
\hline Anthers & $\begin{array}{l}\text { dome shaped, pure white colour, } 4 \text { chambered and deeply seated in column, pollinia yellow colour and laterally compressed } \\
\text { in groups. }\end{array}$ \\
\hline
\end{tabular}

Table 3 Comparison of floral attributes of Phaius hybrid (PBX-11-22) with parents

\begin{tabular}{|c|c|c|c|}
\hline Character & $\begin{array}{l}\text { Phaius hybrid } \\
\text { (PBX-11-22) }\end{array}$ & $\begin{array}{l}\text { P. tankervilleae (Banks ex l'Heritier) Bl. (q } \\
\text { parent) }\end{array}$ & $\begin{array}{l}\text { P. flavus (B1.) Lindl. } \\
\text { (ठ parent) }\end{array}$ \\
\hline Inflorescence length & long & long & medium \\
\hline Flower colour & yellow-orange & brown-purple & yellow \\
\hline Flower nature & spreading \& erect & spreading \& erect & erecto-petal \\
\hline Sepal colour & yellow-orange & brown-purple & yellow \\
\hline Petal colour & yellow-orange & brown-purple & yellow \\
\hline Dorsal sepal shape & oblanceolate & elliptic-oblong & oblong-elliptic \\
\hline Lateral sepals shape & elliptic-lanceolate & elliptic-lanceolate & oblong-elliptic \\
\hline Sepal tip & acute & acute & obtuse tip \\
\hline Petal shape & oblanceolate & oblanceolate & oblong-oblanceolate \\
\hline Petal tip & acute & acute & obtuse tip \\
\hline Lip shape & broad oblong & ovate & oblong \\
\hline Lip nature & Semi-open & tubular & concave \\
\hline Lateral lobes & erect & overlapping & erect \\
\hline Median calli & present & present & present \\
\hline Lip colour & Crimson & pink & Reddish-brown \\
\hline
\end{tabular}

\# PBX-11-22 indicates pedigree code of Plant Breeding crossing register with year $2011 \&$ cross 22 


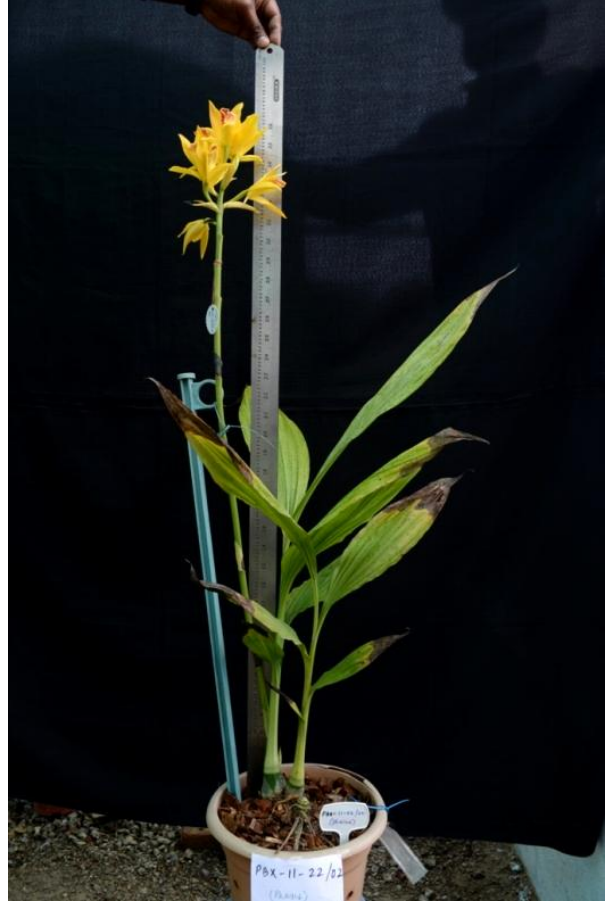

Figure 1. Phaius primary hybrid (PBX-11-22/02)

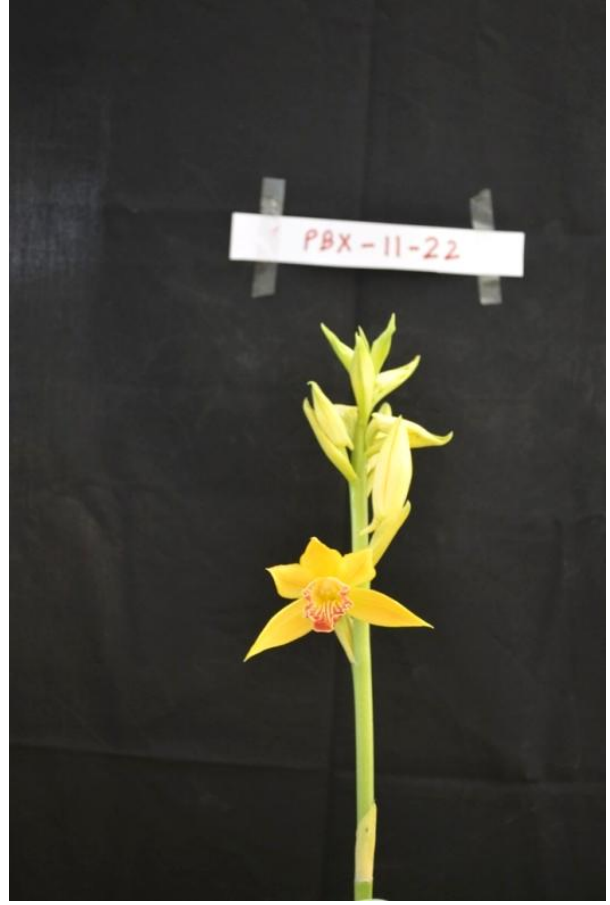

Figure 2. Rachis of Phaius primary hybrid (on 23.02.2017)

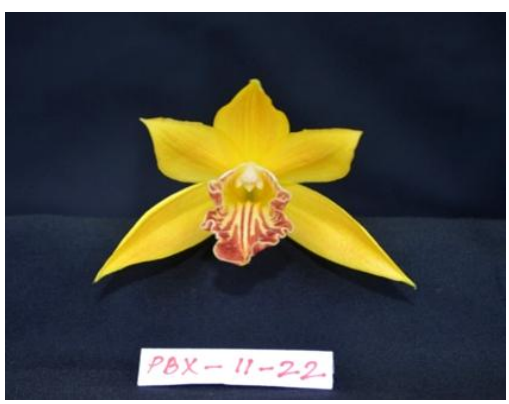

Phaius hybrid F1 flower (PBX-11-22)

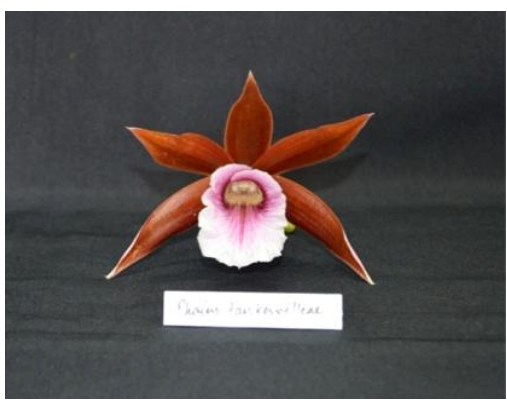

Phaius tankervilleae

(Banks ex l'Heritier) BI. (q parent)

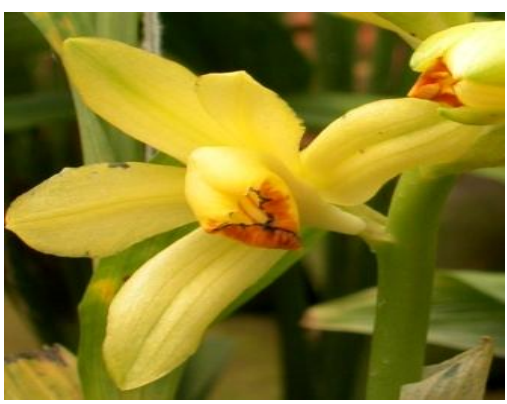

Phaius flavus (BI.) Lindl.(ふ̋ parent)

Figure 3. Comparison of hybrid (PBX-11-22) with female and male parents

plant (Figure 1), inflorescence (Figure 2) and as well as flower configuration along with lip differences was depicted in Figure 3 for identification of specific characters.

The floral configuration of novel Phaius hybrid progeny (PBX11-22) is compared on both front and ventral view to assess the exact shape, size and colour of parts (Figure 4). The floral parts of $P$. tankervilleae, which was used as one of the parent depicted separately for trait comparison (Figure 5). Other parent, $P$. flavus
(\#Old NOAC 659) was lost during course of time from the active collections, due to disease infection and limited population; but morphological characters were compared from previous year's data. The reciprocal combination of same cross, where P. flavus and P. tankervilleae were used as female and male parents (PBX11-25/01) flowered during July-Aug, 2018. The morphological features of plants derived from reciprocal cross are similar to direct cross, except smaller size of flowers and light tinge of pale green colour on tips of sepals and petals (Figure 6). 

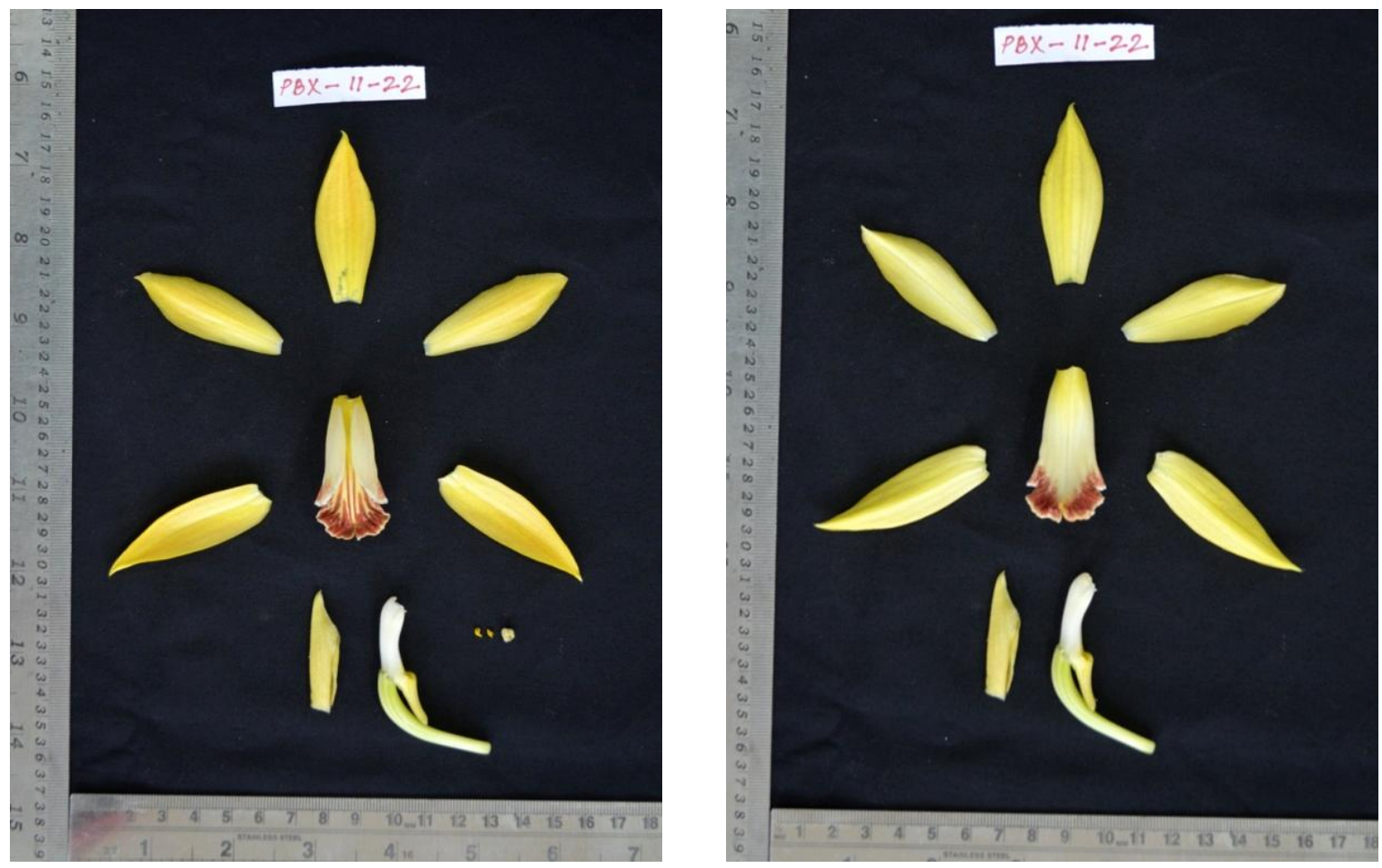

Figure 4. Frontal (R) and ventral (L) view of floral part of Phaius primary hybrid (PBX-11-22)
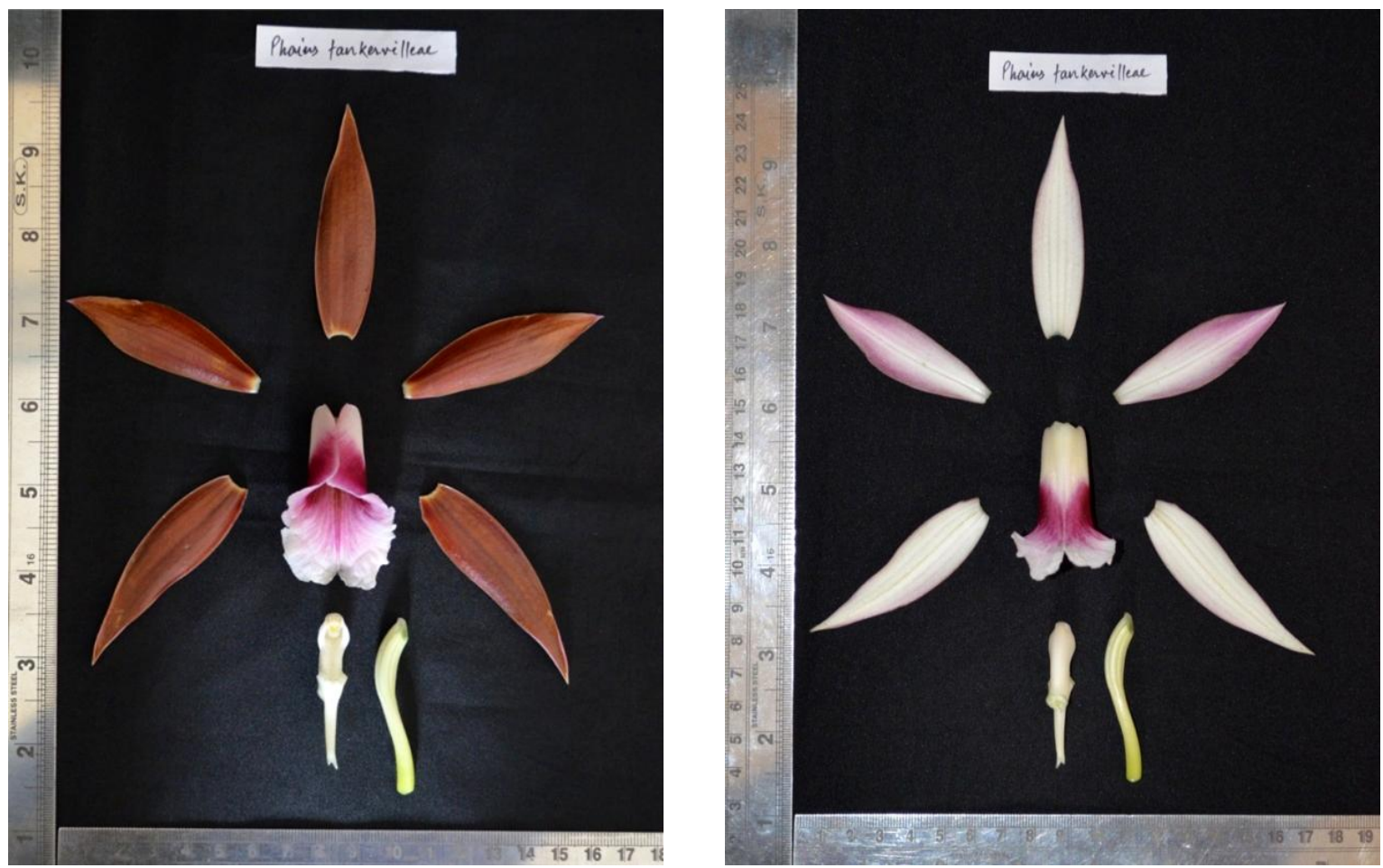

Figure 5. Frontal $(\mathrm{R})$ and ventral $(\mathrm{L})$ view of floral part of Phaius tankervilleae

Journal of Experimental Biology and Agricultural Sciences http://www.jebas.org 

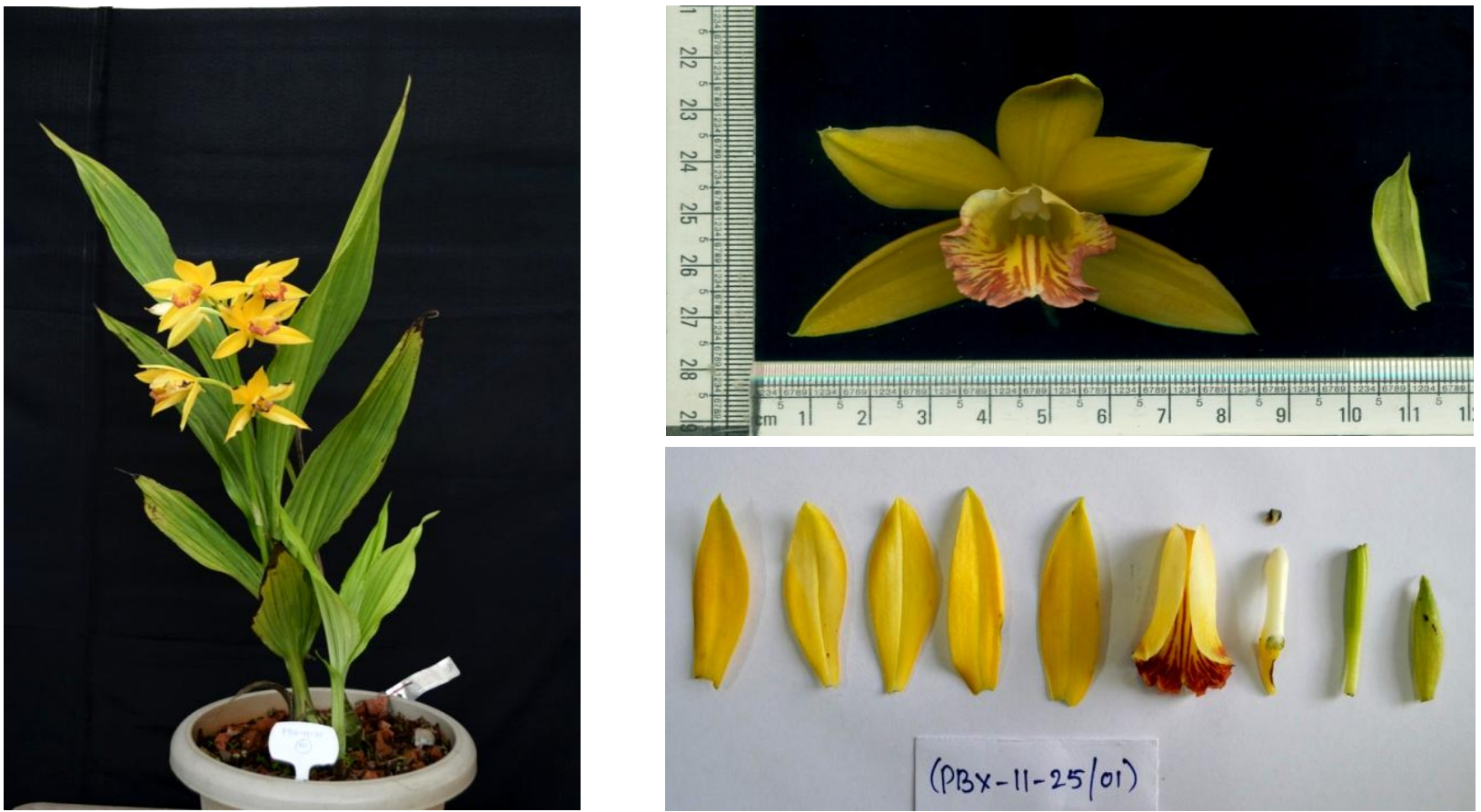

Figure 6. Phaius reciprocal cross (PBX-11-25/01) plant, flower \& floral parts

Phaius flowers produced from both direct (PBX-11-22) and reciprocal (PBX-11-25) crosses are found to be similar in flower traits and colour. The characterization of progenies at F1 stage, indicate the novel features with combined features of floral characters from both parents. The flower colour found to be more attractive due to rich yellow-orange colour, than the yellow coloured P. flavus. The size of sepals and petals were found be intermediate; but shape was similar to $P$. tankervilleae with acute tip. Characters of lip found to be grand with distinct and dark crimson colour with thick stripes starting adjacent to three obscure calli extending up to tip of terminal lobe and spreading all over anterior lobe on yellow-orange back ground. Lateral lobes of lip were erect and semi-open covering above column, similar to $P$. flavus and lip colour sometimes extended towards the lower margin of lateral lobes. In case of P. tankervilleae the lateral lobes were overlapped, which was not found in any Phaius F1 progenies. A similar cross was noticed as 'Joan Hart' by G. Coram from web reference (http://orchids.wikia.com/wiki/Phaius_Joan_Hart; Orchidwiz, 2013) with similar features, but morphological description of plant was not available. In several other countries, Phaius species ranked as endangered species (Harrison et al., 2004; Simmons et al., 2017) and efforts were lacking to develop hybrids through systematic breeding approaches. Hence, the present novel Phaius breeding lines developed can serve as model to develop new varieties.

\section{Conclusion}

This scientific study could be useful for botanists and taxonomist to reassess genetic diversity among species of Phaius and associated gene flow. High incompatibility with other orchid genera indicates narrow genetic base, but found to be compatible within genera and also self compatible. The new primary hybrid from indigenous species developed can serve as an ideal reference material for taxonomical studies and can useful as genetic stock for cultivation as terrestrial plants with good adaptability in sub-tropical conditions. Population development at $F_{2}$ generation may unravel the genetic control of various traits and assist in construction of classical genetic map in Phaius. Further improvement can be done through markers, mutation breeding and hybridization with its near relatives like Calanthe etc.

\section{Acknowledgement}

Authors thank the Dr. R. P. Medhi, Former Director of the institute and acknowledge the contribution of orchid germplasm collections of genus Phaius during 1999-2004 under NATP project by (late) Dr. V. Nagaraju, then Acting Director and Principal Scientist (Horticulture). Authors also thank skilled supporting staff Shri. Dawa Bhutia and Shri. Arjun Gurung for proper field maintenance of Phaius crossed progenies. 


\section{Conflict of interest}

Authors hereby declare that there is no conflict of interest that could possibly arise.

\section{References}

Ackerman JD (2012) Orchids gone wild: Discovering Naturalized Orchids in Hawaii. (Orchids gone wild: Discovering Naturalized Orchids in Hawaii.). Bulletin of the American Orchid Society $81: 88-93$.

Arditti J (1992) Fundamental of Orchid Biology. Wiley, New York.

Arditti J, Jeffrey DC, Flick BH (1971) Post-pollination phenomena in Orchid flowers. III. Effects and interactions of auxin, kinetin or gibberelin. The New Physiologist 70 : 1125-1141.

Bhuyan J (2010) Floral biology of Phaius tankervilleae an endangered terrestrial orchid. Advances in Plant Sciences 23: 611-612

Buragohain B, Chaturvedi SK, Puro N (2016) Pollination biology of Phaius tankervilleae (Banks ex L'Herit) Bl. (Orchidaceae). The International Journal of Plant Reproductive Biology 8: 75-81.

Burg SP, Dijkman J (1967) Ethylene and auxin participation in pollen induced fading of Vanda orchid blossoms. Plant Physiology 42: 1648-1650.

Chowdhery HJ, Agrawala D K (2013) A Century of West Himalayan Orchids. Bishen Singh Mahendra Pal Singh, Dehra dun - 248001, India. pg 318.

CITES (2004) Orchid hybrids exempted from CITES. Available on https://www.cites.org/sites/default/files/common/cop/13/E13P41Annex.pdf access on 25th December, 2018.

CITES (2016) Checklist of CITES Species. Appendix II. UNEPWCMC. Available on http://checklist.cites.org/\#/en access on 25th December, 2018.

Cullen J, Knees S, Cubey HS (2011) The European garden flora, flowering plants: A manual for the identification of plants cultivated in Europe, both out-of-doors and under glass, Second edition. Cambridge, UK: Cambridge University Press.

Desmond R (1995) Kew: The History of Botanic Gardens, UK. The Harvill Press and Royal Botanic Gardens Kew.

Devadas R, Das J, Naik SK, Medhi RP (2008) Influence of potting mixture on acclimatization and growth of in-vitro developed plantlets of Zygopetalum intermedium. Journal of Ornamental Horticulture $11: 241-247$.

Devadas R, Medhi RP, Das SP (2010) Interspecific hybrid in Epidendrum Orchid: E. radicans Pav. ex. Lindl. x E. xanthinum Lindl. Journal of Horticultural Sciences 5 : 144-147.
Edmands S (2002) Does parental divergence predict reproductive compatibility? Trends in Ecology \& Evolution 17: 520-527.

George KV, Mathew J (2016) Phaius tankervilleae (Orchidaceae) - A new record for Southern India. Indian Forester 142 : 300-301.

Harrison DK, Kwan H, Johnston ME, Harris WK (2004) Molecular taxonomy of the Australian swamp orchids (Phaius spp.). Acta Horticulturae [Proceedings of the international symposium on harnessing the potential of horticulture in the Asian-Pacific Region, Coolum, Queensland, Australia, 1-3 September, 2004], No.694: 121-124.

Hirano T, Godo T, Miyoshi K, Ishikawa K, Ishikawa M, Mii M (2009) Cryopreservation and low-temperature storage of seeds of Phaius tankervilleae. Plant Biotechnology Reports3 : 103-109

Kanwal KS (2014) Conservation of Phauis tankervilleae a valuable orchid of Arunachal Pradesh, India. Indian Forester 140 : 1263-1264.

Kishor R, Sharma G J (2009) Intergeneric hybrid of two rare and endangered orchids, Renanthera imschootiana Rolfe and Vanda coerulea Griff. Ex (Orchidaceae): Synthesis and characterization. Euphytica 165 : 247-256. DOI 10.1007/s10681-008-9755-9.

Loureiro J (1790) Phaius grandifolius. Flora Cochinchinensis 2 : 529-530

Lucksom S Z (2007) The Orchids of Sikkim and North East Hilalaya. Concept, Siliguri 734 001, Pp. 607.

Malemnganba H, Bhattacharya S, Deka P C (1994) A new cost effective embryo culture medium for orchids. Journal of the Orchid Society of India (1/2): 67-71

Naithani HB, Chandola S, Chandran M (2009) On the wild occurrence of orchid Phaius tankervilliae in North India. Indian Forester 135: 578-579.

Orchidwiz (2013). Orchidwiz Encyclopedia. Version 9.03. Louisville, USA.

Pearce N R, Cribb P J (2002) The Orchids of Bhutan. Flora of Bhutan including a record of Plants from Sikkim and Darjeeling, Vol 3 (Part 3), Royal Botanic Garden Edinburgh and Royal Government of Bhutan, Pp 643

Schuiteman A, de Vogel EF (2000) Orchid genera of Thailand, Laos, Cambodia and Vietnam. Thai-English edition, Universiteit Leiden, National Herbarium Nederland, The Netherlands. (ISBN 90-7123644-7) Pp. 118

Simmons L, Mathieson M, Lamont R W, Shapcott A (2017) Genetic diversity of endangered orchid Phaius australis across a fragmented Australian landscape. Conservation Genetics 19: 41-465. DOI: 10.1007/s10592-017-1022-y.

Simpson N (2011) Colour and contemporary digital botanical illustration. Optics \& Laser Technology 43 : 330-336 